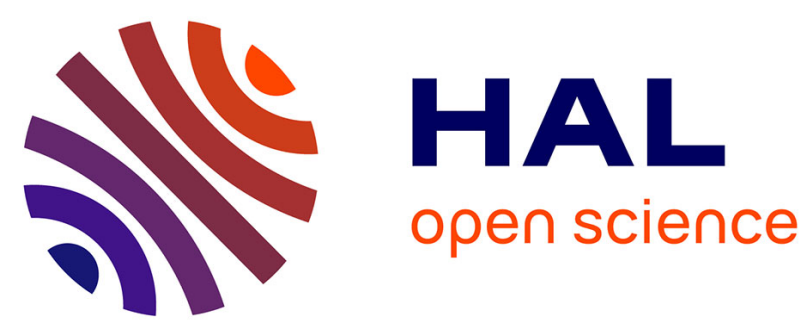

\title{
Euglossine bees (Apidae) in Atlantic forest areas of São Paulo State, southeastern Brazil
}

\author{
Guaraci Duran Cordeiro, Samuel Boff, Tiago Almeida Caetano, Paulo \\ Fernandes, Isabel Alves-Dos-Santos
}

\section{- To cite this version:}

Guaraci Duran Cordeiro, Samuel Boff, Tiago Almeida Caetano, Paulo Fernandes, Isabel Alves-DosSantos. Euglossine bees (Apidae) in Atlantic forest areas of São Paulo State, southeastern Brazil. Apidologie, 2013, 44 (3), pp.254-267. 10.1007/s13592-012-0176-3 . hal-01201293

\section{HAL Id: hal-01201293 \\ https://hal.science/hal-01201293}

Submitted on 17 Sep 2015

HAL is a multi-disciplinary open access archive for the deposit and dissemination of scientific research documents, whether they are published or not. The documents may come from teaching and research institutions in France or abroad, or from public or private research centers.
L'archive ouverte pluridisciplinaire HAL, est destinée au dépôt et à la diffusion de documents scientifiques de niveau recherche, publiés ou non, émanant des établissements d'enseignement et de recherche français ou étrangers, des laboratoires publics ou privés. 


\title{
Euglossine bees (Apidae) in Atlantic forest areas of São Paulo State, southeastern Brazil
}

\author{
Guaraci Duran Cordeiro ${ }^{1}$, Samuel Boff ${ }^{1}$, Tiago de Almeida Caetano ${ }^{2}$, \\ Paulo César Fernandes ${ }^{2}$, Isabel Alves-Dos-SAntos ${ }^{2}$ \\ ${ }^{1}$ Pós-Graduação em Entomologia, Faculdade de Filosofia, Ciências e Letras de Ribeirão Preto, Universidade de São \\ Paulo (USP), Av. Bandeirantes, 3900, Bloco 2, Ribeirão Preto, SP 14040-901, Brazil \\ ${ }^{2}$ Departamento Ecologia, Instituto de Biociências, Universidade de São Paulo, São Paulo, SP 05508-900, Brazil
}

Received 21 February 2012 - Revised 4 October 2012 - Accepted 19 October 2012

\begin{abstract}
We investigated the diversity of euglossine bees in ten areas of Atlantic Forest Domain in São Paulo State, Brazil. Bees were collected with odor baits for 2 years, from March 2007 to March 2009. From a standardized effort during the first year of sampling, we compare the four areas using indexes of diversity, evenness, and similarity of euglossine communities. In the second year, we added six new places for presenting a general overview on the Atlantic forest in São Paulo. A total of 2,395 individuals of 23 species were recorded in the study areas. Ilhabela had the highest number of species (19) and individuals $(1,260)$. The most attractive odor bait was eucalyptol, which attracted 16 species and $58 \%$ of all individuals. Euglossa cordata (Linnaeus 1958 ) was the most abundant species, representing $50 \%$ of the individuals sampled; apparently, populations of this species are more abundant at low altitudes, as for example on islands and on the coast. The results also suggest a difference in richness among altitudes, since coastal areas (where the climatic variation are milder) had more species. The present study advances knowledge on the occurrence of euglossine bees in the Atlantic Forest and fills the lack of a systematic study of these bees of coastal areas in São Paulo State.
\end{abstract}

orchid bees / pollinators / diversity / deforestation / conservation

\section{INTRODUCTION}

The Atlantic Forest Domain extends along the Brazilian coast between $5^{\circ}$ and $31^{\circ}$ South latitude (Almeida 2000), forming a north-south corridor through which bee species can disperse and have contact with each other (Alves dos Santos 1999). In the state of São Paulo, $15 \%$ of the Atlantic Forest is left; its remnants are located close to the coast, mainly in the region of Vale do Ribeira, in the scarps of the mountain ranges Serra do Mar and Serra da Mantiqueira, and in coastal plains (Fundação SOS Mata

Corresponding author: G. Duran Cordeiro, guaradc@usp.br

Manuscript editor: Klaus Hartfelder
Atlântica/INPE 2009). Despite some remnants being left, destruction is accelerated; this biome is destroyed even before a full understanding of its rich biodiversity (Kageyama and Gandara 2000). According to Ribeiro et al. (1987), more than $80 \%$ of the fragments are $<50$ ha. Due to the accelerated loss of Atlantic Forest remnants, systematic sampling is necessary. Because bees of the tribe Euglossini (Apidae) are relatively abundant throughout the year, easy to capture and taxonomically well described (Powell and Powell 1987; Brosi 2009), they are good models for systematic sampling. Because of these aspects, the tribe Euglossini is of value for conservation studies of forest remnants (Becker et al. 1991; Tonhasca et al. 2002; Brosi 2009; Nemésio and Silveira 2010). 
The tribe Euglossini consists of approximately 208 species comprising five genera: Euglossa Latreille, Eulaema Lepeletier, Eufriesea Cockerell, Aglae Lepeletier \& Seville, and Exaerete Hoffmannsegg; the last two are exclusively composed of cleptoparasitic species (Moure et al. 2007). This bee tribe is distributed in the Neotropics where it occurs in different environments from Mexico to Argentina (between $29^{\circ} \mathrm{N}$ and $32^{\circ} \mathrm{S}$ ) (Michener 2000). The species richness of this group is highest in rainforests (Moure 1967; Dressler 1982).

The genus Euglossa is highest in richness and is followed in this sequence by Eufriesea, Eulaema, Exaerete, and Aglae (Moure et al. 2007). A review of the occurrence and distribution of euglossine bees in the Atlantic Forest reported 54 species (Nemésio 2009), but several new species have since been described (Nemésio and Rasmussen 2011).

Euglossini males collect fragrances from flowers, mainly of orchids; they are responsible for the pollination and reproduction of these plants (Dressler 1982). Dodson et al. (1969) synthesized aromatic substances similar to flower odors in order to attract males with artificial baits. In this way, inventories and studies on community and population dynamics of Euglossini were greatly facilitated (Janzen et al. 1982; Ackerman 1983; Pearson and Dressler 1985; Roubik and Ackerman 1987; Silva and Rebêlo 2002; Roubik and Hanson 2004).

In Brazil, many inventories of euglossine bees have been carried out with aromatic baits, including Atlantic Forest of several states (Wittmann et al. 1988; Raw 1989; Neves and Viana 1997; Rebêlo and Garófalo 1997; Peruquetti et al. 1999; Bezerra and Martins 2001; Viana et al. 2002; Santos and Sofia 2002; Tonhasca et al. 2002, 2003; Sofia and Suzuki 2004; Martins and Souza 2005; Souza et al. 2005; Nemésio and Silveira 2006, 2007a; Aguiar and Gaglianone 2008, 2011, 2012; Farias et al. 2008; Ramalho et al. 2009; Sydney et al. 2010; Mattozo et al. 2011).

The present study aimed at investigating species richness, abundance, seasonality, and preference for different odor baits of euglossine bees in Atlantic Forest areas of São Paulo State.

\section{MATERIALS AND METHODS}

The study was carried out over 2 years, from March 2007 to March 2009 in Atlantic Rainforest areas of São Paulo State, southeastern Brazil. The predominant type of vegetation in all areas sampled is Ombrophilous Dense Forest. Four areas were sampled monthly during 1 year: Boracéia Biological Station, Neblinas Park, Ilhabela State Park, and Serra da Cantareira State Park (Figure 1). In the second year, these localities were sampled as follows: Ilhabela continued to be sampled monthly, whereas Boracéia, Neblinas and Cantareira were sampled from September 2008 to March 2009.

Boracéia Biological Station $\left(23^{\circ} 38^{\prime} \mathrm{S}-45^{\circ} 52^{\prime} \mathrm{W}\right)$ is located within a reserve of Sabesp (Basic Sanitation Company of the State of São Paulo) in Salesópolis; it has 16,450 ha, and its altitude varies from 750 to $900 \mathrm{~m}$ a.s.l. Neblinas Park $\left(23^{\circ} 45^{\prime} \mathrm{S}-\right.$ $46^{\circ} 09^{\prime} \mathrm{W}$ ) is located within the municipalities of Mogi das Cruzes and Bertioga, has 2,800 ha, and its altitude varies from 700 to $1,100 \mathrm{~m}$ a.s.l. Ilhabela State Park $\left(23^{\circ} 45^{\prime} \mathrm{S}-45^{\circ} 27^{\prime} \mathrm{W}\right)$ is located in municipality of Ilhabela (the largest continental island in the São Paulo State), has 27,025 ha, and its altitude varies from 0 to $1,378 \mathrm{~m}$ a.s.l. Serra da Cantareira State Park $\left(23^{\circ} 22^{\prime} \mathrm{S}-46^{\circ} 36^{\prime} \mathrm{W}\right)$ is located within the municipalities of São Paulo, Guarulhos, Mairiporã, and Franco da Rocha, has $8,000 \mathrm{ha}$, and its altitude varies from 950 to $1,074 \mathrm{~m}$ a.s.l. The first three localities are in very good conservation status, whereas in Serra da Cantareira State Park there is a strong influence of the metropolitan region, and consequently, secondary vegetation predominates.

In addition to these four localities, we carried out sampling in São Sebastião (Guaecá beach) $\left(23^{\circ} 45^{\prime} \mathrm{S}-\right.$ $45^{\circ} 24^{\prime} \mathrm{W}$ ), a continental area near to Ilhabela, every month from June 2008 to June 2009, except for October 2008 and February and May 2009, giving a total of nine sampling months. Five other sites were sampled only once and thus were considered as additional localities. They were: Santa Genebra Forest $\left(22^{\circ} 50^{\prime} \mathrm{S}-47^{\circ} 07^{\prime} \mathrm{W}\right), 670 \mathrm{~m}$ a.s.l. (February 2008); Bertioga $\left(23^{\circ} 51^{\prime} \mathrm{S}-46^{\circ} 08^{\prime} \mathrm{W}\right)$ and Cananéia $\left(25^{\circ} 01^{\prime} \mathrm{S}-47^{\circ} 56^{\prime} \mathrm{W}\right)$, at sea level (February 2009); Vitória Island $\left(23^{\circ} 44^{\prime} \mathrm{S}-45^{\circ} 01^{\prime} \mathrm{W}\right)$ and Búzios Island $\left(23^{\circ} 48^{\prime} \mathrm{S}-45^{\circ} 08^{\prime} \mathrm{W}\right)$, also at sea level belonging to 


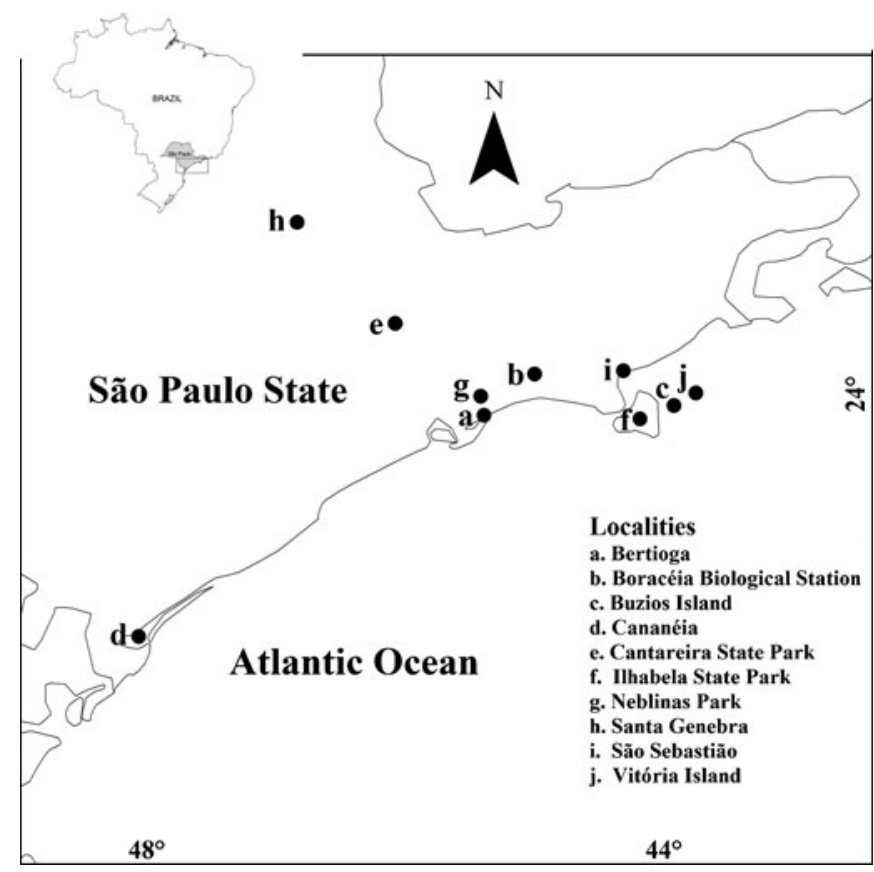

Figure 1. Location of study areas where euglossine bees were collected in São Paulo State.

the archipelago encompassed by Ilhabela State Park (January 2009).

Sampling was carried out on sunny days from 9 to $17 \mathrm{~h}$. The odor baits used to attract males in the first year were eucalyptol, eugenol, and vanillin (Ilhabela, Cantareira, Neblinas, and Boracéia). In the second year, for all areas, the following odor baits were added: amyl acetate, benzyl acetate, phenylic alcohol, benzyl benzoate, beta-ionone, methyl butyrate, ethyl cinnamate, methyl cinnamate, cineol, myrcene, and methyl salicylate. For all localities, odor baits were offered on two ways by means of a cotton ball tied with a string to trees at ca. $1.5 \mathrm{~m}$ height (in this case bees were actively collected with an entomological net) and passive sampling in traps made of PET bottles with three funnel-shaped side entrances, containing cotton balls with odor baits (in this case, bees were trapped). Ten to 15 drops of each odor bait were applied on the cotton balls. Bees were sacrificed, identified, and deposited in the Entomological Collection Paulo Nogueira Neto (CEPANN) of the Biosciencies Institute of University of São Paulo.
For calculating indices of diversity, evenness, and similarity of euglossine communities, we used only data of the four localities sampled monthly for 1 year (Boracéia, Neblinas, Ilhabela, and Cantareira). To estimate diversity, we used the indices of Shannon $\left(H^{\prime}\right)$ (Pielou 1975) and Simpson (D) (Magurran 1988). Representativeness of each species in a given area was calculated by means of evenness indices (ED) based on the Simpson and the Shannon indices (Pielou 1975). To compare species composition among areas (4) sampled with the same effort, we used the Sørensen similarity coefficient (Cs) (Sørensen 1948). To calculate all aforementioned indices, we used the program PAST 1.85 (Hammer et al. 2001). For the similarity analysis based on species composition and abundance, we used the Morisita-Horn index (Cmh) (Morisita 1959) implemented in the program Lizaro Morisita CalcV1.0. After calculating the results for the first year sampled with standardized effort, additional surveys were included and the results of these different effort compared by means of a rarefaction analysis imple- 
mented in the program PAST 1.85 (Hammer et al. 2001).

\section{RESULTS}

\subsection{Standardized sampling efforts study}

In the localities sampled with standardized effort for 1 year (Boracéia, Neblinas, Ilhabela, and Cantareira), the abundance of males and the number of species were different among studied areas (Table I) and were also higher in the warmer months (November to March) (Table II).

For Neblinas Park, the highest diversity indices were denoted, followed by Cantareira, Boracéia, and Ilhabela (Table III). The paired similarity in species composition among study areas calculated with the Sørensen coefficient varied from 0.48 to 0.82 (Table V). Boracéia and Neblinas $(\mathrm{Cs}=0.82)$ shared the highest number of species (seven species in common). Ilhabela and Cantareira were the least similar areas in terms of species composition $(\mathrm{Cs}=$ 0.48). Although they also had six species in common, this number represented less than half of the species found in Ilhabela. The similarity calculated with the Morisita-Horn index, which considers the relative abundance of each species, varied between 0.06 and 0.73 (Table V). According to this index, Neblinas and Cantareira were the most similar areas, with six species in common.

\subsection{Total sampling results}

After a first year of sampling in the four areas studied with standardized effort (Boracéia, Neblinas, Ilhabela, and Cantareira), additional six places were sampled with different efforts. This resulted in a total of 2,395 males from 23 Euglossini species (Table I). Ilhabela contributed with the highest number of species (19) and individuals $(1,260)$, representing over $50 \%$ of the individuals sampled (Table I). With different sampling efforts applied in the second year of the study, we generated rarefaction curves to equalize the efforts to total sampling (Figure 2). The genus Euglossa was the richest in species (14), followed by Eufriesea (5), Eulaema (3), and Exaerete (1). Euglossa cordata (Linnaeus 1958) was the only species common to all localities, representing approximately $50 \%$ of all sampled individuals (Table I).

The most attractive odor bait for both years was eucalyptol. Eucalyptol attracted 16 species and approximately $58 \%$ of all males (Table IV). Some odor baits introduced in the second year -benzyl acetate, benzyl benzoate, beta-ionone, and methyl salicylate-increased the number of species with the capture of Euglossa anodorhynchi Nemésio, 2006, Eufriesea aeneiventris Mocsáry, 1896, and Eulaema seabrai Moure, 1960.

\section{DISCUSSION}

The occurrence of euglossine bees in Atlantic Forest areas throughout Brazil was reported by Nemésio (2009), with a recent update of the checklist for this biome by Nemésio and Rasmussen (2011). In the present study, we recorded 23 species for all studied areas, which correspond to approximately $40 \%$ of the euglossine species known for this biome.

Our results are partially consistent with the richness of this tribe reported for southeastern Brazil (Nemésio 2009) and southern Bahia (Neves and Viana 1997). In southern Brazil, where the predominant climate is subtropical, there is a gradual reduction in species richness of euglossine bees (Wittmann et al. 1988; Sofia and Suzuki 2004; Mattozo et al. 2011). The euglossine fauna sampled in our study comprises species with wide distribution along the north-south corridor of the Atlantic Forest, such as Euglossa cordata (treated as Euglossa carolina by Nemésio 2009) and Eulaema nigrita Lepeletier, 1841, which occur from the states of Rio Grande do Norte ( $\left.5^{\circ} \mathrm{S}\right)$ to Rio Grande do $\mathrm{Sul}\left(30^{\circ} \mathrm{S}\right)$, as well as species that predominate in the southeastern region, such as Euglossa fimbriata Moure, 1968 and Euglossa securigera Dressler 1982 (Peruquetti et al. 1999). 


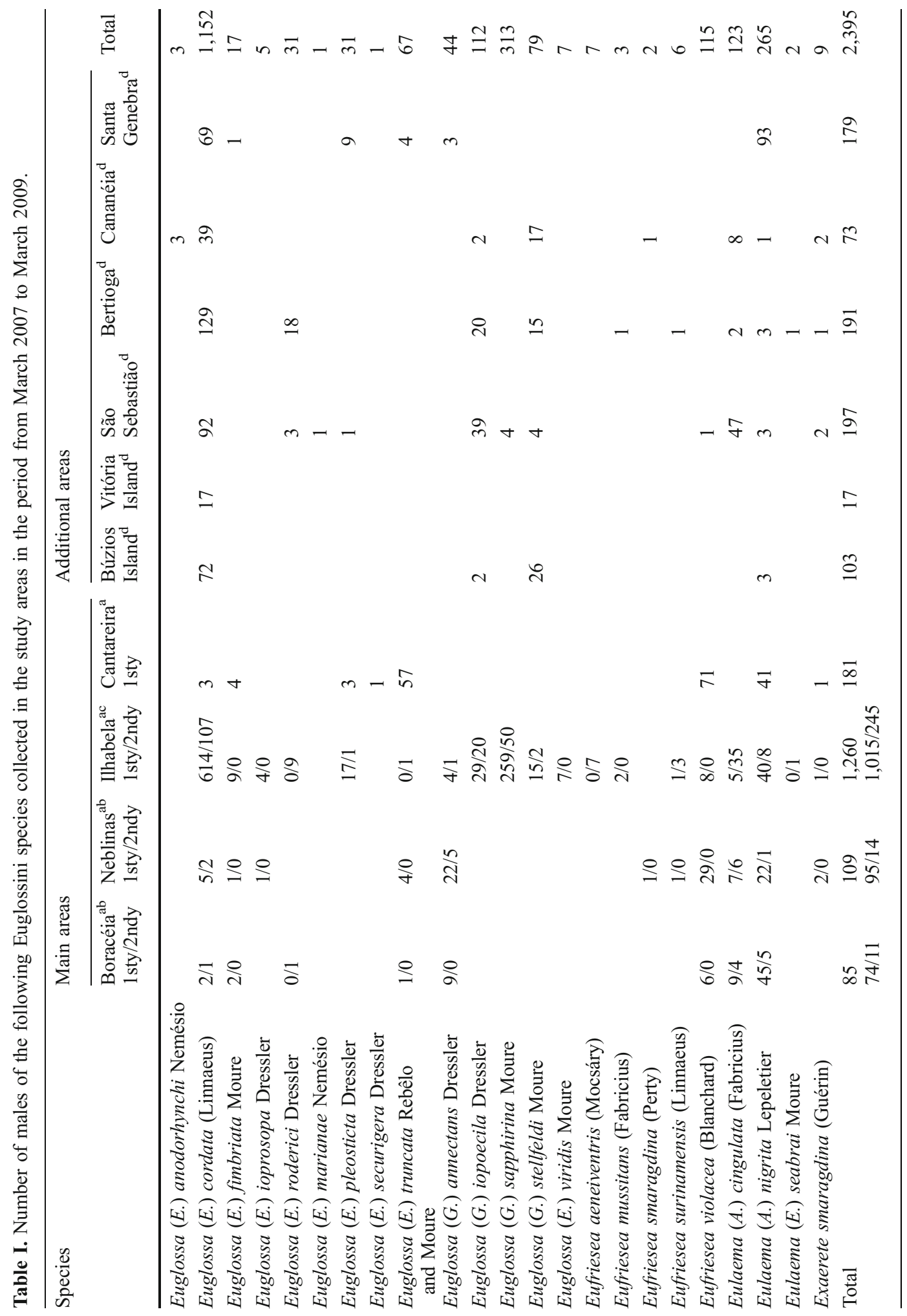




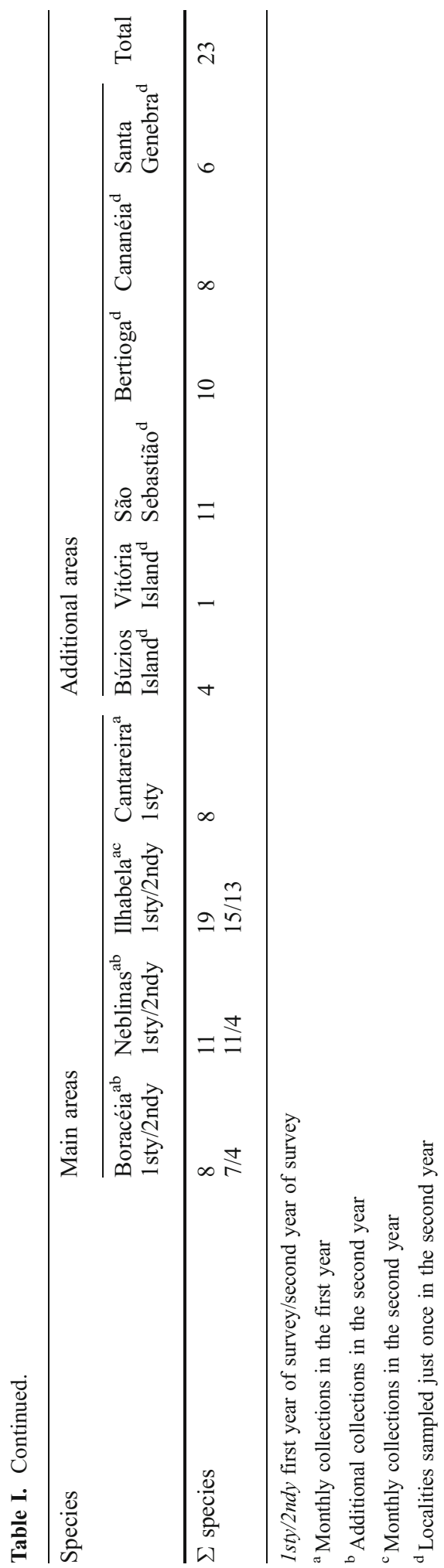

The number of species sampled in studies on euglossine bees must be analyzed with caution, due to the differences and adjustments between sampling methods (Morato 1998). For this reason and to avoid wrong interpretation, we divided our data into two groups, the first for the results of the four different areas with the standardized sampling effort [one full year (2007-2008), same odor baits] and the other representing the results of the additional efforts, including the use of additional aromatic baits.

In Ilhabela, the locality with the highest number and periodicity of sampling (monthly during 2 years), we recorded the highest number of species (19), with 15 in the first year and 4 additional species in second year. Even after the equalization efforts with rarefaction techniques, Ilhabela remained the area with the highest species richness of all areas sampled. On the other hand, for the remaining areas, the curve continued to grow, inferring that additional species may still be sampled in these areas. In São Sebastião, a continental area approximately $3 \mathrm{~km}$ distant from Ilhabela and where sampling was done during 9 months, 11 species were recorded, with 10 being in common with Ilhabela. As São Sebastião presents well preserved sites, including areas within the Serra do Mar State Park, we believe that other species that were not surveyed this time may occur in this area. Although some localities were sampled on a single day only, the results were surprising with regard to species richness, such as in the coastal regions of Bertioga (10 species) and Cananéia (8). The low number of species recorded on the islands Búzios (4) and Vitória (1) is possibly due to an island effect, since these islands are smaller and more distant from the continent than Ilhabela. In rapid assessments (single day sampling) in the Brazilian Cerrado, Nemésio and Faria (2004a) collected species numbers similar to our rapid assessments (Bertioga and Cananeia). This strategy of intensive sampling (single day or few days) has been shown to be very useful, with number of species similar to 1 year of monthly samplings (Nemésio 2011). 


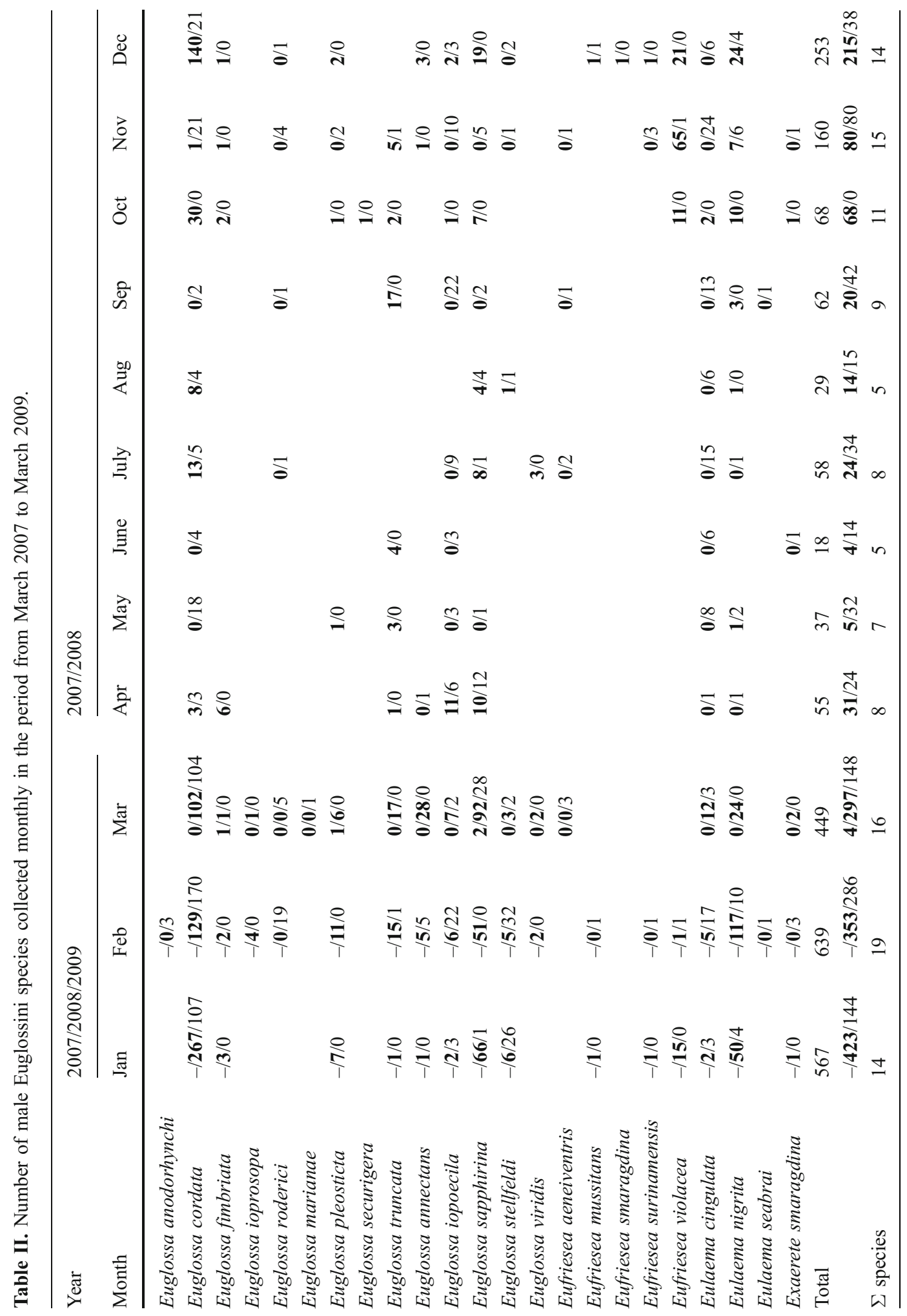




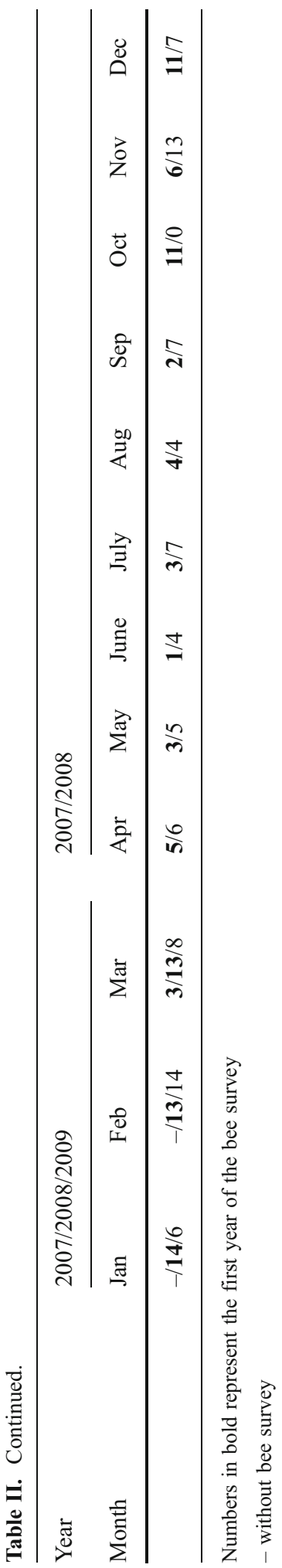

Euglossa cordata was the most abundant species, representing approximately $50 \%$ of all individuals sampled. This species proved to be a generalist with regard to odor baits (it was attracted to 12 out of 14 odor baits used) and is active throughout the year since it was sampled in all months and all sampling sessions. Euglossa cordata is probably a multivoltine species. Silva and Rebêlo (2002) found similar results, since they also sampled this species during successive surveys (12 months). The number of individuals of Euglossa cordata captured in different areas varied between 3 and 721. Due to the very high number of Euglossa cordata individuals sampled in some areas (as in Ilhabela), this species seems to be associated with low local diversity indices, as inferred by Tonhasca et al. (2002). However, it seems that populations of Euglossa cordata are more abundant at low altitudes (Nemésio and Silveira 2007b), as for instance on islands (Ilhabela, Búzios, and Vitória) and on the coast (São Sebastião, Bertioga, and Cananéia). In Boracéia and Neblinas, for example, which are located above $700 \mathrm{~m}$ a.s.l. and are very close (around $9 \mathrm{~km}$ ) to Bertioga, only three and seven specimens, respectively, were collected. On the other hand, in Bertioga (at the sea level), 129 individuals were captured on a single day. Surprisingly, in coastal areas sampled in São Paulo State and Paraná State by Mattozo et al. (2011), Euglossa cordata was not captured.

Euglossa annectans Dressler 1982, Euglossa truncata Rebêlo and Moure, 1996, and Eufriesea violacea Blanchard, 1840 seem to be mainly associated with highlands, since $90 \%$ of the individuals were captured above 700 ma.s.1.. Other studies also reported the presence of Euglossa annectans at higher altitudes in São Paulo State (Garófalo et al. 1998) and Rio de Janeiro State (Aguiar and Gaglianone 2012). Our data also corroborate that Eufriesea violacea and Euglossa truncata are typical of inland areas (e.g., Cantareira) as indicated previously (Sofia and Suzuki 2004; Nemésio and Silveira 2007b).

The second most abundant species in our study was Euglossa sapphirina Moure, 1968 
Table III. Simpson's dominance (c), Simpson's diversity $(D)$, Shannon-Wiener's diversity $\left(H^{\prime}\right)$, Simpson's evenness (ED), and Shannon-Wiener's evenness $\left(J^{\prime}\right)$ for the four study areas sampled monthly in the period from March 2007 to February 2008.

\begin{tabular}{llllll}
\hline Study areas & \multicolumn{6}{l}{ Index of diversity } \\
\cline { 2 - 6 } & $c$ & $D$ & $H^{\prime}$ & ED & $J^{\prime}$ \\
\hline Boracéia & 0.41 & 0.59 & 1.27 & 0.51 & 0.65 \\
Parque das Neblinas & 0.21 & 0.79 & 1.75 & 0.58 & 0.76 \\
Ilhabela & 0.43 & 0.57 & 1.22 & 0.22 & 0.45 \\
Cantareira & 0.31 & 0.69 & 1.34 & 0.48 & 0.65 \\
\hline
\end{tabular}

(treated as Euglossa crassipunctata by Nemésio 2009), which is also widely distributed in the Atlantic Forest, from the states of Paraíba to Paraná (Moure et al. 2007; Nemésio 2009). This species is considered as an indicator of good conservation status for Atlantic Forest fragments (Nemésio and Silveira 2006; Ramalho et al. 2009). However, out of the 313 individuals collected, 309 were captured exclusively on Ilhabela and 4 in São Sebastião. The conditions of these localities are in agreement with the findings of Milet-Pinheiro and Schlindwein (2005) and Nemésio and Silveira (2006), who inferred that Euglossa sapphirina is restricted to tropical areas with dense and interior forests. In addition, it is apparently restricted to low altitudes, as observed by Ramalho et al. (2009) in the state of Rio de Janeiro.

The high number of euglossine species (nine exclusive species), and their high abundance (77\% of the individuals) collected in coastal areas, is probably a result of milder climatic conditions, with less temperature variation and a mild winter. According to Roubik and Hanson (2004), areas with milder conditions would have higher species richness and diversity. Furthermore, it is expected that larger and less disturbed forest fragments provide more floral resources, and they should consequently have higher species richness of bees (Peruquetti et al. 1999; Ramalho et al. 2009; Nemésio and Silveira 2010). Our results support

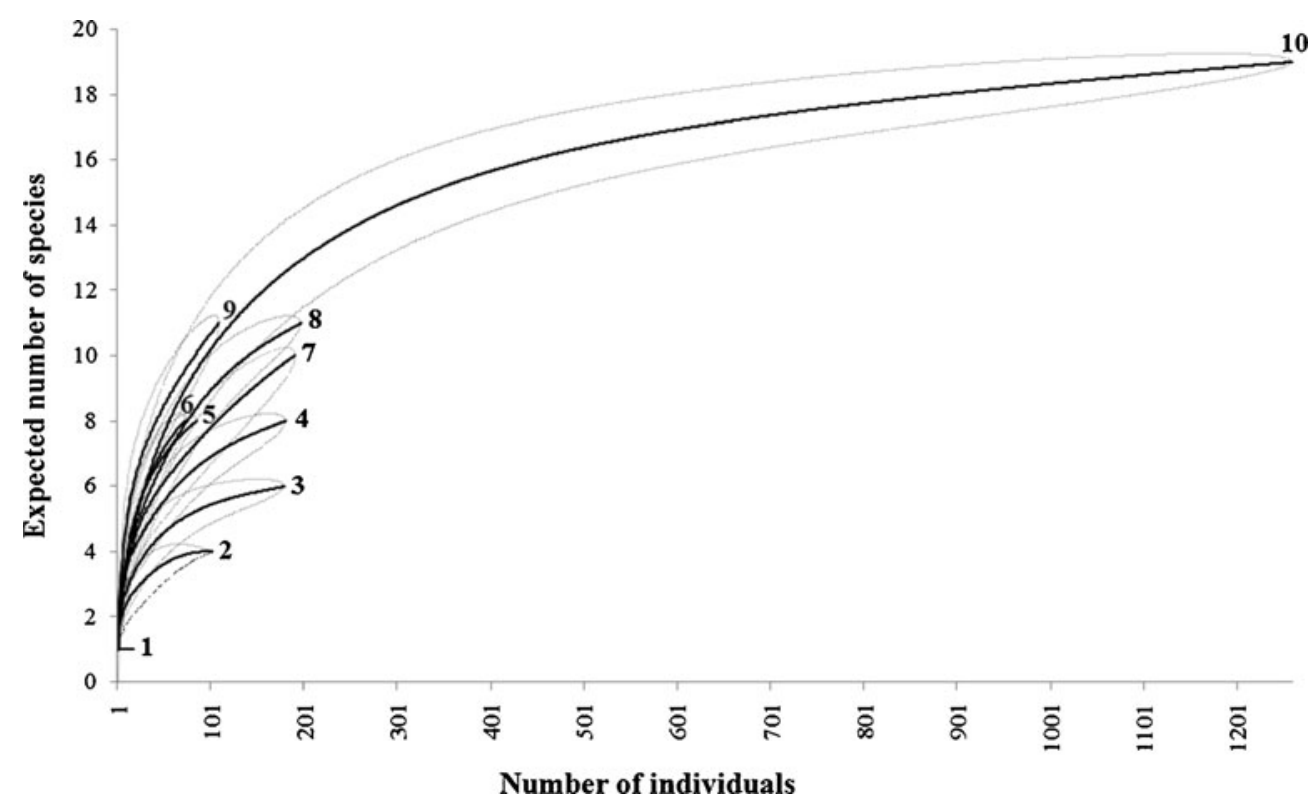

Figure 2. Rarefaction curve for species richness of euglossine bees for ten areas sampled in São Paulo State, southeastern Brazil. 1 Vitória Island, 2 Buzios Island, 3 Santa Genebra, 4 Cantareira, 5 Boracéia, 6 Cananéia, 7 Bertioga, 8 São Sebastião, 9 Neblinas, 10 Ilhabela. 
Table IV. Number of males of the following Euglossini species collected in odor baits in the period from March 2007 to March 2009.

\begin{tabular}{|c|c|c|c|c|c|c|c|c|c|c|c|c|c|c|}
\hline Species & AA & BA & PA & $\mathrm{BB}$ & BI & MB & $\mathrm{EC}$ & $\mathrm{MC}$ & CI & $\mathrm{EG}^{\mathrm{a}}$ & $\mathrm{EU}^{\mathrm{a}}$ & MI & MS & $\mathrm{VA}^{\mathrm{a}}$ \\
\hline Euglossa anodorhynchi & & & & 3 & & & & & & & & & & \\
\hline Euglossa cordata & & 1 & 1 & 7 & 182 & 6 & 2 & 21 & 96 & 20 & 790 & 1 & & 25 \\
\hline Euglossa fimbriata & & & & & & & & & & 1 & 16 & & & \\
\hline Euglossa ioprosopa & & & & & & & & & & & 5 & & & \\
\hline Euglossa roderici & & & & 3 & 4 & 1 & 2 & 1 & & & 1 & & 19 & \\
\hline Euglossa marianae & & & & & & & & & & & & & & 1 \\
\hline Euglossa pleosticta & & & & & & & & & & 2 & 23 & & & 6 \\
\hline Euglossa securigera & & & & & & & & & & & 1 & & & \\
\hline Euglossa truncata & & & 2 & & & & & & & 60 & 3 & & & 2 \\
\hline Euglossa annectans & & & & & 2 & 1 & & & & 25 & 16 & & & \\
\hline Euglossa iopoecila & & & & 3 & & & & & 15 & 49 & 42 & 2 & 1 & \\
\hline Euglossa sapphirina & & & & & & & & & 17 & 7 & 213 & & & 76 \\
\hline Euglossa stellfeldi & 6 & & & 6 & 20 & 7 & & & & 20 & 17 & 1 & & 2 \\
\hline Euglossa viridis & & & & & & & & & & 6 & & & & 1 \\
\hline Eufriesea aeneiventris & & & & & 1 & & & & & & & & 6 & \\
\hline Eufriesea mussitans & & & & & & & & & & & 2 & & & 1 \\
\hline Eufriesea smaragdina & & & & & & & & & & & & & & 2 \\
\hline Eufriesea surinamensis & & & 1 & & & & & & & & & 1 & & 4 \\
\hline Eufriesea violacea & & & & & & & & & 1 & & 38 & & & 76 \\
\hline Eulaema cingulata & & 25 & & & 9 & & & 9 & 8 & 27 & 2 & & & 43 \\
\hline Eulaema nigrita & & & & & & & 1 & & 4 & 3 & 221 & & & 36 \\
\hline Eulaema seabrai & & 1 & & & 1 & & & & & & & & & \\
\hline Exaerete smaragdina & & & & & & & & & 1 & 2 & 3 & & 1 & 2 \\
\hline Total & 6 & 27 & 4 & 22 & 219 & 15 & 5 & 31 & 142 & 222 & 1393 & 5 & 27 & 277 \\
\hline$\Sigma$ species & 1 & 3 & 3 & 5 & 7 & 4 & 3 & 3 & 7 & 12 & 16 & 4 & 4 & 14 \\
\hline
\end{tabular}

$A A$ amyl acetate, $B A$ benzyl acetate, $P A$ phenylic alcohol, $B B$ benzyl benzoate, $B I$ beta-ionone, $M B$ methyl butyrate, $E C$ ethyl cinnamate, $M C$ methyl cinnamate, $C I$ cineol, $E G$ eugenol, $E U$ eucalyptol, $M I$ myrcene, $M S$ methyl salicylate, $V A$ vanillinin

${ }^{a}$ Odor baits used in both years

this idea, since Ilhabela State Park, with over 27,000 ha of preserved area and little human impact, had the highest number of species.

According to Morato et al. (1992), Peruquetti et al. (1999), and Tonhasca et al. (2002), Eulaema nigrita can be considered as an indicator of degraded areas. This species is abundant even in small fragments (Nemésio and Silveira 2007a; Aguiar and Gaglianone 2012). In the present study, Eulaema nigrita was found in less preserved areas, such as in Cantareira, a park in the metropolitan region of São Paulo (where
41 individuals were found), and in Santa Genebra, a park in the metropolitan region of Campinas (with 93 individuals recorded), as well as in areas with well preserved forests, e.g., Boracéia with 50 individuals (58\%). Hence, this species appears to be less sensitive to changes in the environment and in fragment size, corroborating Sofia and Suzuki (2004), who suggested that Eulaema nigrita is able to survive or explore forest fragments of different sizes.

Regarding the similarity between study areas (see Boracéia, Neblinas, Ilhabela, and Cantar- 
Table V. Similarity between the four study areas sampled monthly, depending on the species composition (Sørensen) and abundance of individuals (Morisita) in the period from March 2007 to February 2008.

\begin{tabular}{lcc}
\hline Study areas & Sørensen & $\begin{array}{l}\text { Morisita- } \\
\text { Horn }\end{array}$ \\
\hline Boracéia $\times$ Parque das Neblinas & 0.82 & 0.6828 \\
Parque das Neblinas $\times$ Cantareira & 0.66 & 0.7341 \\
Boracéia $\times$ Cantareira & 0.66 & 0.4729 \\
Parque das Neblinas $\times$ Ilhabela & 0.64 & 0.1413 \\
Boracéia $\times$ Ilhabela & 0.55 & 0.1016 \\
Ilhabela $\times$ Cantareira & 0.48 & 0.0607 \\
\hline
\end{tabular}

eira; Table V), sampled with standardized effort for 1 year, the indices varied between 0.48 and 0.82 , showing that almost half of the species sampled are common to most localities, and indicating that only few species are restricted to a single area. The similarity with respect to abundance had high amplitude (0.06-0.73) due to the large variation in the abundance of particular species across the sampled areas. Notwithstanding, we observed that most exclusive species were recorded on Ilhabela (7) and in other few coastal areas (Table I). Species composition is also less similar when the region of Ilhabela is compared with the three areas sampled above $700 \mathrm{~m}$ a.s.l. (Table V). The high similarity observed between Boracéia and Neblinas was expected because they are mutually closer than the other studied areas and are located almost at the same altitude. According to Brosi (2009), geographic proximity and altitude are important variables that influence the similarity of euglossine communities. In relation to evenness, our results (Table III) are similar to those of several other studies in Atlantic Forest (e.g., Rebêlo and Garófalo 1997; Sofia and Suzuki 2004; Ramalho et al. 2009): few species were represented by many individuals and many species were represented by few individuals. This pattern seen in the Atlantic Forest seems to be inverse to that of the Amazon region, where diversity is high and there are few dominant species (Nemésio 2007; Storck-Tonon et al. 2009). The diversity in
Boracéia, with a richness of 13 species, was probably limited by the dominance of two species, Eulaema nigrita and Eulaema cingulata (Fabricius, 1804), which represented $74 \%$ of the sampled specimens.

Some species were sampled in almost all months of the year. However, between November and March, which are the warmest and wettest months in the study areas, individuals of all species were captured. The period between April and August had the largest gaps in terms of species representativeness and abundance of individuals. Between June and August (winter and drought period), only 98 individuals of five species were captured. This seasonal pattern may be related to factors such as flowering (Pearson and Dressler 1985), nest activity, emergence (Rebêlo and Garófalo 1991), and climate. In view of these results, future inventories of euglossine bees in these regions, or even specific studies on their biology, should concentrate efforts during spring and summer.

In particular, the species of Eufriesea exhibited a seasonal activity concentrated between November and February. This is typical for most species of this genus, which are active during few months (Kimsey 1982). In Panamá, some species of Eufriesea are active throughout the year (Ackerman 1983). However, Eufriesea aeneiventris was collected in March, July, and September, which are months outside the usual pattern expected for Eufriesea in our localities. Furthermore, the capture of seven individuals of Eufriesea aeneiventris, a very rare species reported by Nemésio and Silveira (2004b), has even further enhanced the conservation status of Ilhabela.

Among odor baits, eucalyptol was the most attractive essence concerning the number of species and individuals collected, as also observed in several other studies (Ackerman 1983; Raw 1989; Rebêlo and Garófalo 1991; Neves and Viana 1997; Peruquetti, et al. 1999; Bezerra and Martins 2001; Viana et al. 2002; Sofia and Suzuki 2004). The three most abundant species (Euglossa cordata, Euglossa sapphirina, and Eulaema nigrita) were also captured with other baits, although they were strongly attracted to eucalyptol. The use of new odor baits in the second 
year showed good results in the attraction of bees that were not recorded in the first year, adding 3 species and 503 individuals to our sample.

The present study presents the first record for the capture of Euglossa anodorhynchi in odor baits (benzyl benzoate). The studied area where this species was collected (Cananéia) is relatively near (around $70 \mathrm{~km}$ ) localities sampled by Mattozo et al. (2011), but Euglossa anodorhynchi was not attracted to odor baits in that study area, even though it was expected to be present (Melo et al. 2008). Euglossa anodorhynchi is probably attracted by benzyl benzoate only, which was not used by Mattozo et al. (2011).

Although the use of odor baits greatly facilitates the capture of euglossine males, other sampling methods should be also considered, as for example trap nests (Garófalo et al. 1993). In the four localities sampled in the first year, three nests of Euglossa were captured (two of Euglossa anodorhynchi and one of Euglossa truncata) in Boracéia in bamboo canes (G.D. Cordeiro, unpublished data). Euglossa anodorhynchi was not attracted to odor baits in this locality.

The results presented herein contribute to the knowledge on the occurrence of euglossine bees in the Atlantic Forest. Hence, it would be important to use these results as subsidies to elaborate and design strategies for conservation and management of euglossine bees, as well as studies on population genetics, which would lead to a better understanding of fragmentation effects in the Atlantic Forest.

\section{ACKNOWLEDGMENTS}

We are very grateful to our colleagues Carina Oliveira de Abreu, Eduardo Pinto, Héber Couto, Mariana Taniguchi, and Morgana Sazan for help in field and laboratory work; André Nemésio and Leo Correia da Rocha for identifying several euglossine species; Teresa Cristina Giannini for elaborating the map; and the staff of the Boracéia Biological Station, Neblinas Park (Instituto Ecofuturo), Ilhabela State Park and Serra da Cantareira State Park and the Instituto Florestal from São Paulo for permission to collect and support in the field. Biota-FAPESP provided financial support (processes: 07/51911-2; 04/00274-4; 04/15801-0).

\begin{abstract}
Abeilles euglossines (Apidae) dans des zones de la forêt atlantique de l'Etat de São Paulo, au sud-est du Brésil.
\end{abstract}

\begin{abstract}
Abeilles à orchidée / pollinisateurs / diversité / déforestation / conservation
\end{abstract}

\section{Euglossine Bienen (Apidae) im Atlantischen Regenwald des Staates São Paulo, Südostbrasilien}

Prachtbienen / Bestäuber / Artenvielfalt / Entwaldung / Ökosystemerhaltung

\section{REFERENCES}

Ackerman, J.D. (1983) Diversity and seasonality of male euglossine bees (Hymenoptera: Apidae) in central Panamá. Ecology 64, 274-283

Aguiar, W.M., Gaglianone, M.C. (2008) Comunidade de abelhas Euglossina (Hymenoptera: Apidae) em remanescentes de mata estacional semidecidual sobre tabuleiro no estado do Rio de Janeiro. Neotrop. Entomol. 37, 118-125

Aguiar, W.M., Gaglianone, M.C. (2011) Euglossine bees (Hymenoptera Apidae Euglossina) on an inselberg in the Atlantic Forest domain of southeastern Brazil. Trop. Zool. 24, 107-125

Aguiar, W.M., Gaglianone, M.C. (2012) Euglossine bee communities in small Forest fragments of the Atlantic Forest, Rio de Janeiro state, southeaster Brazil (Hymenoptera, Apidae). Rev. Bras. Entomol. 56, 210-219

Almeida, D.S. (2000) Recuperação ambiental da Mata Atlântica, Ilhéus, BA. Ed. Edittus, Ilhéus

Alves dos Santos, I. (1999) Abelhas e plantas melíferas da Mata Atlântica, restinga e dunas do litoral norte do estado do Rio Grande do Sul, Brasil. Rev. Bras. Entomol. 43, 191-223

Becker, P., Moure, J.S., Peralta, F.J.A. (1991) More about euglossine bees in Amazonian forest fragments. Biotropica 23, 586-591

Bezerra, C.P., Martins, C.F. (2001) Diversidade de Euglossinae (Hymenoptera, Apidae) em dois fragmentos de Mata Atlântica localizados na região urbana de João Pessoa, Paraíba, Brasil. Rev. Bras. Zool. 18, 823-835

Brosi, B.J. (2009) The effects of forest fragmentation on Euglossini bee communities (Hymenoptera: Apidae: Euglossini). Biol. Conserv. 142, 414-423

Dodson, C.H., Dressler, R.L., Hills, H.G., Adams, R.M., Williams, N.H. (1969) Biologically active compounds in orchid fragrances. Science 164, 12431249

Dressler, R.L. (1982) Biology of the orchid bees (Euglossini). Annu. Rev. Ecol. Syst. 13, 373-394 
Farias, R.C.A.P., Madeira-da-Silva, M.C., PereiraPeixoto, M.H., Martins, C.F. (2008) Composição e sazonalidade de espécies de Euglossina (Hymenoptera: Apidae) em mata e duna na Área de Proteção Ambiental da Barra do Rio Mamanguape, Rio Tinto, PB. Neotrop. Entomol. 37, 253-258

Fundação SOS Mata Atlântica/INPE (2009) Atlas dos remanescentes florestais da Mata Atlântica. Ed. Instituto Nacional de Pesquisas Espaciais

Garófalo, C.A., Camillo, E., Serrano, J.C., Rebêlo, J.M.M. (1993) Utilization of trap nests by Euglossini species (Hymenoptera:Apidae). Rev. Bras. Biol. 53, 77-87

Garófalo, C.A., Camillo, E., Augusto, S.C., Jesus, B.M.V., Serrano, J.C. (1998) Nest structure and communal nesting in Euglossa (Glossura) annectans Dressler (Hymenoptera, Apidae, Euglossini). Rev. Bras. Zool. 15, 589-596

Hammer, O., Harper, D.A.T., Ryan, P.D. (2001) PAST: Paleontological statistics software package for education and data analyses. Paleontol. Electrôn. 4

Janzen, D.H., Devries, P.J., Heggins, M.L., Kimsey, L.S. (1982) Seasonal and site variation in Costa Rica euglossine bees at chemical baits in lowland deciduous and evergreen forests. Ecology 63, 66-74

Kageyama, P.Y., Gandara, F.B. (2000) Recuperação de áreas ciliares. In: Rodrigues, R.R., Leitão Filho, H.F. (eds.) Matas ciliares (conservação e recuperação), pp. 249-269. EDUSP; FAPESP, São Paulo

Kimsey, L.S. (1982) Systematics of bees of the genus Eufriesea. Univ. Calif. Publ. Entomol. 95, 1-125

Magurran, A.E. (1988) Ecological diversity and its measurements. Princeton University Press, Princeton

Martins, C.F., Souza, A.K.P. (2005) Estratificação vertical de abelhas Euglossina (Hymenoptera, Apidae) em uma área de Mata Atlântica, Paraíba, Brasil. Rev. Bras. Zool. 22, 913-918

Mattozo, V.C., Faria, L.R.R., Melo, G.A.R. (2011) Orchid bees (Hymenoptera: Apidae) in the coastal forest of southern Brazil: diversity, efficiency of sampling methods and comparison with other Atlantic forest surveys. Pap. Avul. Zool. 51, 505-515

Melo, G.A.R., Faria, L.R.R., Marchi, P., Carvalho, C.J.B. (2008) Small orchid bees are not safe: parasitism of two species of Euglossa (Hymenoptera: Apidae: Euglossina) by canopied flies (Diptera: Canopidae). Rev. Bras. Zool. 25, 573-575

Michener, C.D. (2000) The Bees of the World. Johns Hopkins University Press, Baltimore

Milet-Pinheiro, P., Schlindwein, C. (2005) Do euglossine males (Apidae, Euglossini) leave tropical rainforest to collect fragrances in sugarcane monocultures? Rev. Bras. Zool. 22, 853-858

Morato, E.F. (1998) Estudos sobre comunidades de abelhas Euglossini. Anais do Encontro sobre Abelhas, Ribeirão Preto, pp. 135-143
Morato, E.F., Campos, L.A.O., Moure, J.S. (1992) Abelhas Euglossini (Hymenoptera, Apidae) coletadas na Amazônia Central. Rev. Bras. Entomol. 36, 767-771

Morisita, M. (1959) Measuring of interespecific association and similarity between communities. Mem. Fac. Sci. Kyushu Univ. Ser. E (Biol.) 3, 65-80

Moure, J.S. (1967) A checklist of the known euglossine bees. Atas do Simpósio sobre a Biota Amazônica 5, 395-415

Moure, J.S., Melo, G.A.R., Faria Jr., L.R.R. (2007) Euglossini Latreille, 1802. In: Moure, J.S., Urban, D., Melo, G.A.R. (eds.) Catalogue of Bees (Hymenoptera, Apoidea) in the Neotropical Region, pp. 214-255. Sociedade Brasileira de Entomologia, Curitiba

Nemésio, A. (2007) The community structure of male orchid bees along the Neotropical region. Rev. Bras. Zool. 9, 151-158

Nemésio, A. (2009) Orchid bees (Hymenoptera: Apidae) of the Brazilian Atlantic Forest. Zootaxa 2041, 1-242

Nemésio, A. (2011) Euglossa marianae sp. n. (Hymenoptera: Apidae): a new orchid bee from the Brazilian Atlantic Forest and the possible first documented local extinction of a Forest-dependent orchid bee. Zootaxa 2892, 59-68

Nemésio, A., Faria, L.R.R. (2004a) First assessment of the orchid bee-fauna (Hymenoptera: Apidae) at Parque Estadual do Rio Preto, a cerrado area in southeastern Brazil. Lundiana 5, 113-117

Nemésio, A., Silveira, F.A. (2004b) Biogegraphic notes on rare species of Euglossina (Hymenoptera: Apidae: Apini) ocurring in the Brazilian Atlantic Rain Forest. Neotrop. Entomol. 33, 117-120

Nemésio, A., Silveira, F.A. (2006) Edge effects on the orchid bee fauna (Hymenoptera: Apidade: Apini: Euglossina) at a large remnant of Atlantic Rain Forest in southeastern Brazil. Neotrop. Entomol. 35, 313-323

Nemésio, A., Silveira, F.A. (2007a) Orchid bee fauna (Hymenoptera: Apidae: Euglossina) of Atlantic Forest fragments inside an urban area in southeastern Brazil. Neotrop. Entomol. 36, 186-191

Nemésio, A., Silveira, F.A. (2007b) Diversity and distribution of orchid bees (Hymenoptera: Apidae: Euglossina) with a revised check list of their species. Neotrop. Entomol. 36, 874-888

Nemésio, A., Silveira, F.A. (2010) Forest fragments with large core areas better sustain diverse orchid bee faunas (Hymenoptera: Apidae: Euglossina). Neotrop. Entomol. 39, 555-561

Nemésio, A., Rasmussen, C. (2011) Nomenclatural issues in the orchid bees (Hymenoptera: Apidae: Euglossina) and an update catalogue. Zootaxa 3006, 1-42

Neves, E.L., Viana, B.F. (1997) Inventário da fauna de Euglossinae (Hymenoptera: Apidae) do baixo sul da Bahia, Brasil. Rev. Bras. Zool. 4, 831-837 
Pearson, D.L., Dressler, R.L. (1985) Two-year study of male orchid bee (Hymenoptera: Apidae: Euglossini) attraction to chemical baits in lowland south-eastern Peru. J. Trop. Ecol. 1, 37-54

Peruquetti, R.C., Campos, L.A.O., Coelho, C.D.P., Abrantes, C.V.M., Lisboa, L.C.O. (1999) Abelhas Euglossini (Apidae) de áreas de Mata Atlântica: Abundância, riqueza e aspectos biológicos. Rev. Bras. Zool. 16, 101-118

Pielou, E.C. (1975) Ecological diversity. John Wiley \& Sons, New York

Powell, A.H., Powell, V.N. (1987) Population dynamics of male euglossine bees in Amazonian forest fragments. Biotropica 19, 176-179

Ramalho, A.V., Gaglianone, M.C., Oliveira, M.L. (2009) Comunidades de abelhas Euglossina (Hymenoptera, Apidae) em Fragmentos de Mata Atlântica. Rev. Bras. Entomol. 53, 95-101

Raw, A. (1989) The dispersal of euglossine bees between isolated patches of eastern Brazilian wet forest (Hymenoptera: Apidae). Rev. Bras. Entomol. 33, 103-107

Rebêlo, J.M.M., Garófalo, C.A. (1991) Diversidade e sazonalidade de machos de Euglossinae (Hymenoptera: Apidae) e preferência por iscas-odores em um fragmento de floresta no sudeste do Brasil. Rev. Bras. Biol. 51, 787-799

Rebêlo, J.M.M., Garófalo, C.A. (1997) Comunidades de machos de Euglossinae (Hymenoptera, Apidae) em matas semidecíduas do nordeste do estado de São Paulo. An. Soc. Entomol. Bras. 26, 243-256

Ribeiro, M.C., Metzger, J.P., Martensen, A.C., Ponzoni, F., Hirota, M.M. (1987) Brazilian Atlantic Forest: How much is left and how is the remaining forest distributed? Implications for conservation. Biol. Conserv. 142, 1141-1153

Roubik, D.W., Ackerman, J.D. (1987) Long-term ecology of euglossine orchid-bees (Apidae, Euglossini) in Panama. Oecologia 73, 321-333

Roubik, D.W., Hanson, P.E. (2004) Orchid bees of tropical America: biology and field guide. INBIO, San Jose

Santos, A.M., Sofia, S.H. (2002) Horário de atividade de machos de Euglossinae (Hymenoptera, Apidae) em um fragmento de floresta semidecídua no norte do estado do Paraná. Acta Sci. 24, 375-381

Silva, F.S., Rebêlo, J.M.M. (2002) Population dynamics of euglossinae bees (Hymenoptera, Apidae) in an early second-growth forest of Cajual Island, in the state of Maranhão, Brazil. Braz. J. Biol. 62, 15-23

Sofia, S.H., Suzuki, K.M. (2004) Comunidades de machos de abelhas Euglossina (Hymenoptera: Apidae) em fragmentos florestais no sul do Brasil. Neotrop. Entomol. 33, 693-702

Sørensen, T. (1948) A method for establishing groups of equal amplitude in plant sociology based on similarity of species content and its application to analyses of the vegetation on Danish commons. Biol. Skrif. 5, 1-34

Souza, A.K.P., Hernándes, M.I.M., Martins, C.F. (2005) Riqueza, abundância e diversidade de Euglossina (Hymenoptera, Apidae) em três áreas da Reserva Biológica Guaribas, Paraíba, Brasil. Rev. Bras. Zool. 22, 320-325

Storck-Tonon, D., Morato, E.F., Oliveira, M.L. (2009) Fauna de Euglossina (Hymenoptera: Apidae) da Amazônia Sul-Ocidental, Acre, Brasil. Acta Amazon. 39, 693-706

Sydney, N.V., Gonçalves, R.B., Faria, L.R.R. (2010) Padrões espaciais na distribuição de abelhas Euglossina (Hymenoptera, Apidae) da região Neotropical. Pap. Avul. Zool. 50, 667-679

Tonhasca Jr., A., Blackmer, J.L., Albuquerque, G.S. (2002) Abundance and diversity of euglossine bees in the fragmented landscape of the Brazilian Atlantic Forest. Biotropica 34, 416-422

Tonhasca Jr., A., Albuquerque, G.S., Blackmer, J.L. (2003) Dispersal of euglossine bees between fragments of the Brazilian Atlantic Forest. J. Trop. Ecol. 19, 99-102

Viana, B.F., Kleinert, A.M.P., Neves, E.L. (2002) Comunidade de Euglossini (Hymenoptera, Apidae) das dunas litorâneas do Abaeté, Salvador, Bahia, Brasil. Rev. Bras. Entomol. 46, 539-545

Wittmann, D., Hoffmann, M., Scholz, E. (1988) Southern distributional limits of euglossine bees in Brazil linked to habitats of the Atlantic and subtropical rain forest (Hymenoptera, Apidae, Euglossini). Entomol. Gen. 14, 53-60 